\title{
The Wet Cupping Therapy Stimulates Inflammatory Responses
}

\author{
Wahyudi Widada \\ Departement of Medical Surgical \\ Faculty of Health Science in Muhammadiyah \\ University of Jember, \\ Jakarta, Indonesia \\ wahyudiwidada@unmuhjember.ac.id
}

\begin{abstract}
Body has a great immune system among others of lymphocytes population. The biggest parts are $\mathbf{T}$ (timus) cell, $B$ (bone) cell and Natural Killer cell (NK). $\mathrm{T} \mathrm{CD8}^{+}$cell is destroying cell infected by virus and tumor cell, while NK cell is natural killer cell in mechanism of inflammatory responses. Cupping therapy is a treatment method with the principle of trauma to the skin in the form of cupping and wounding. The general purpose of this research is to prove the effect of cupping on the enhancement of $T$ $\mathrm{CD8}^{+}$and NK cells as inflammation responses. The research design is quasi experimental by using nonrandom pretest posttest without control group design that is done towards human being as the research subject. The treatments of cupping therapy are done in Jember for two weeks on the twenty people research subjects. All of the research subjects are taken their venous blood as much as $\mathbf{2} \mathrm{ml}$ in the median cubiti vein area then are done cupping therapy in seven points. Cupping areas are Al-Akhda'ain 2 points, Al-Kahil 1 point, Al-Katifain 2 points and Ala Warik 2 points. The next blood samplings are in the fiveteenth day. Blood checking uses flow cytometry is done in Laboratory of Medical Faculty in Brawijaya University of Malang. After collecting the data, data analyses are done computerized by using ANOVA test because it is homogeny and the normality test is fulfilled. The measurement results obtained $T$ CD8+ cell mean values in pretreatment was 34.56, in post treatment mean value was 63.26, standard deviation was 7.41 with $p$ value was 0.00 smaller than 0.05. In pretreatment, NK cell mean value was 16.25 and in post treatment mean value was 35.50 , standard deviation was 5.17 , the test was using ANOVA obtained p value was $0.00<0.05$. There was significance difference in value of $\mathrm{T} C D 8+$ and NK cells in pre post treatments. So, cupping therapy is able to stimulate the inflammation response by producing $\mathrm{T}$ CD8+ and NK cells.
\end{abstract}

Keywords-cupping; T cell; NK cell, CD8+, immune cells

\section{INTRODUCTION}

Lymphocytes T cell is a cell in one of leukocytes cell groups which is known as lymphocytes and played main role in cellular immunity. Lymphocytes $\mathrm{T}$ cell can distinguish kinds of pathogens by ability evolved over time for improving immune systems in every time the body is exposed to the pathogen. It maybe because of amount of lymphocytes $T$ cells are activated into memory lymphocytes $\mathrm{T}$ cell with the capabilities to multiply quickly to fight recurrent infections. T CD8+ cell is T cell population that has a function of defense against intracellular pathogens [1].
Lymphocytes are granular leukocytes that play a role in specific defense. It is called specific because it is only done by leukocytes lymphocytes cell, forming immunity after triggering by antigen which is resulting in the formation of antibodies. Every antibody is specific to certain antigen. Lymphocytes play a role in immune that is brokered cell and antibody. In all adult lymphocytes, the surfaces are attached to the antigen receptors that are only able to recognize one antigen. When antigen comes into body, the certain molecules bind themselves to antigen and bring them up in front of lymphocytes. These molecules are made by gen that is called Major Histocompatibility Complex I (MHC I) molecule. MHC I presents antigen in front of $\mathrm{T}$ cytotoxic lymphocytes (TCD8 ${ }^{+}$ cell), and MHC II presents antigen to the front of $\mathrm{T}$ helper lymphocytes ( $\mathrm{T} \mathrm{CD} 4^{+}$cells). T lymphocytes cell is made in the bone marrow of the pluripotent stem cells and matured in thymus. T CD8 ${ }^{+}$, attack the infected body cells by pathogen [2].

$\mathrm{T} \mathrm{CD} 8^{+}$lymphocytes cell contains azurophilic granular very much and is able to break various infected cells, tumor cells and normal cells, without sensitization before. It is classified as innate immune system which is the first layer of body defense towards various attacks. In general, B-cell stimulation is dependent upon help gained from T cells. Multiple mechanisms exist to regulate the function of self-recognizing $\mathrm{T}$ lymphocytes including peripheral deletion mechanisms, induction of anergy and active suppression of self-reacting lymphocytes. Immunopathology of autoimmune diseases involves participation of autoantibodies, complement activation and disorders related to cell-mediated and humoral immunity [3].

The mechanism of tissue damage is equal to the mechanism that is used by $\mathrm{T}$ cell for eliminating cell that relates to microbial. $\mathrm{T} \mathrm{CD} 4^{+}$cell reacts towards antigen in cell or tissue, occurs secretion of cytokines that induce inflammation and activate macrophages. $\mathrm{T} \mathrm{CD} 8^{+}$cell can ruin the cell that binds to foreign antigens. In many autoimmune diseases that are brokered by $\mathrm{T}$ cell, there are specific $\mathrm{T} \mathrm{CD} 4^{+}$and $\mathrm{T} \mathrm{CD} 8^{+}$cells for self antigen, and both of them play a role on tissue damage. The evidences in experimental show that antibacterial defense are macrophages and T lymphocytes. Mononuclear phagocyte cells or macrophages play a role as main effectors while $\mathrm{T}$ lymphocytes as protection or immune supporter [3] 
The wet cupping is a treatment method by blood damaged letting because of oxidants or free radicals from the body through skin surface [4]. Cupping is a treatment method by using tubes or vacuum glasses that put on skin surface in order to make a local barrage. In wet cupping therapy, containment is followed by bloodletting [5].

\section{METHODS}

The research design is quasi experimental by using nonrandom pretest - posttest without control group design that is done towards human being as the research subject. The research is done in Jember, East Java for two weeks. Blood checking is done in Biomedical Laboratory of Medical Faculty in Brawijaya University of Malang. The samples are 20 people.

Venous blood is as much as $2 \mathrm{ml}$ taken in the median cubiti vein to checkup either $\mathrm{T} \mathrm{CD} 8^{+}$cell or NK cell, taken before and after treatment in time span two weeks. The treatments of cupping therapy are done in Jember for two weeks on the twenty people research subjects. All of the research subjects are taken their venous blood as much as $2 \mathrm{ml}$ in the median cubital vein then are done cupping therapy in seven points. Cupping areas are Al-Akhda'ain 2 points, Al-Kahil 1 point, Al-Katifain 2 points and Ala Warik 2 points. The next blood samplings are in the fourteenth day. Blood is packed in the bottles which have been given anticoagulant EDTA that are going to be flow cytometry checked up next. Blood checking uses flowcytometry is done in Laboratory of Medical Faculty in Brawijaya University of Malang. After collecting the data, pre and post treatments, then data analyses are done computerized by using ANOVA test.

\section{RESULT AND DISCUSSION}

The result of this study is $\mathrm{T} \mathrm{CD}^{+}$cell in group of pretreatment can be obtained mean was 34.56 , SD was 4.75 , the lowest value was 24.65, the highest value was 41.36. Meanwhile, the value of T CD8+ cell in the post treatment has mean was 63.26 , SD was 7.41, the lowest value was 51.26, highest value was 86.35 . The normality test used One-Sample Kolmogorov-Smirnov Test that can be significance (2-tailed) the value of $\mathrm{T} \mathrm{CD8}^{+}$cell 0.154 , which is more than 0.05 , means the distributed normal data. The homogeneity test and Varian linearity and Covariant in variable use Levene's Test of Equality of Error Variances can be obtained significance of T CD8+ cell 0.335 , which is more than 0.05 , means it is homogeny.

TABLE I. THE RESULT OF MEASUREMENT CD8 ${ }^{+}$CELL IN PRE AND POST TREATMENT

\begin{tabular}{|c|c|c|c|c|c|c|c|}
\hline & $\begin{array}{c}\text { Group of } \\
\text { research }\end{array}$ & $N$ & Mean & SD & $\begin{array}{c}\boldsymbol{p} \\
\text { value }\end{array}$ & Min & Max \\
\hline $\begin{array}{c}\text { Group } \\
\text { of T } \\
\text { CD8 } \\
\text { Cell }\end{array}$ & $\begin{array}{c}\text { Pre } \\
\text { Treatment }\end{array}$ & \multirow{2}{*}{20} & 34.56 & 4.75 & & 24.65 & 41.36 \\
\cline { 2 - 4 } & $\begin{array}{c}\text { Post } \\
\text { Treatment }\end{array}$ & & 63.26 & 7.41 & & 51.26 & 86.35 \\
\hline
\end{tabular}

Because of the normality data test of cell T CD8+ is normal, and the homogeneity test is fulfilled, so the test use ANOVA that can be obtained from $p$ value $<0,05$ which means there is a difference between pre and post cupping treatment.
There is significant increasing mean value from 34.56 to 63.26 that shows has been raising mechanism immune system, in this case is T CD8 +cell. Lymphocyte leucocytes have significantly increased the number and effects directly on the increasing its function. Lymphocyte $\mathrm{T}$ cell is a cell in one of leucocytes cell's group, which is known as main role in cellular immune. Lymphocyte $\mathrm{T}$ cell is able to differentiate pathogen with evolution ability all the time for increasing immunity every time the body is exposed by the pathogen. It is possibly because an amount of Lymphocyte $\mathrm{T}$ cell is activated to be lymphocyte $\mathrm{T}$ cell memory with ability to breed quickly to against the infection that maybe occur again [6].

According to Ilkay C., Mark B., Roz G. (2005) shows that mechanism of breakage tissue is equal as mechanism used by lymphocyte $\mathrm{T}$ cell to eliminate cell related to microbe. Lymphocyte $\mathrm{T} \mathrm{CD} 4^{+}$cells react towards antigen in the cell or tissue, happen cytokines secretion that inducts inflammation and activate macrophage. The breakage tissue is caused cytokines secretion from macrophage and others inflammation cells. T $\mathrm{CD}^{+}$Cell can ruin cell that banded with foreign antigen. In much autoimmune disease that is mediated by lymphocyte $\mathrm{T}$ cell, may obtained $\mathrm{T} \mathrm{CD} 4^{+}$cell and $\mathrm{CD}^{+}$cell specifically for antigen itself, and both of them play role in breakage tissue.

Experimentally proof shows that anti micro bacteria defense is macrophage and lymphocyte T. Mononuclear phagocyte cell or macrophage plays role as main effectors meanwhile lymphocyte $\mathrm{T}$ as supported protection or immune. This specific immune system cause of doing by only lymphocyte leukocyte cells form immune of body, triggered by antigen (foreign compound) until forming antibody and every specific antibody for certain antigen. Lymphocyte plays role in immunity that is mediated between cell and antibody [7].

Lymphocyte cell $\mathrm{T}$ activation gives different respond such as antibody production, phagocyte cell activation or breakage target cell immediately. Therefore, the imitation immune of antibody respond toward various disease to be practiced. $\mathrm{T} \mathrm{CD} 8^{+}$ cell is population. Lymphocyte $\mathrm{T}$ cytholitic cell has defense function towards intracellular pathogen in experimentation animal. Not like $\mathrm{CD}^{+}$cell, $\mathrm{T} \mathrm{CD} 8^{+}$cell does not produce IL-2 but it depends on exogen resource [6].

$\mathrm{TCD}^{+}$cells in raising defense system by joining other defense system. Knowing the foreign material by immune system by itself, it does not only produce breakage material itself. Cell from immune system takes down chemistry messenger (like cytokine) which take and activate other cell like polimort, macrophage and mast cell or chemistry system (like complement, amine, kinin, and lisosomal system) to break foreign material [1].

\section{TABLE II. MEASUREMENT NK CELL PRE AND POST GETTING CUPPING}

\begin{tabular}{|c|c|c|c|c|c|c|c|}
\hline & $\begin{array}{c}\text { Group of } \\
\text { research }\end{array}$ & $N$ & Mean & $S D$ & $\begin{array}{c}p \\
\text { value }\end{array}$ & Min & Max \\
\hline \multirow{2}{*}{$\begin{array}{c}\text { Group } \\
\text { of NK } \\
\text { Cell }\end{array}$} & $\begin{array}{c}\text { Pre } \\
\text { Treatment }\end{array}$ & \multirow{2}{*}{20} & 16.25 & 3.29 & & 10 & 23 \\
\cline { 4 - 5 } & $\begin{array}{c}\text { Post } \\
\text { Treatment }\end{array}$ & & 35.50 & 5.17 & & 22 & 45 \\
\hline
\end{tabular}


$\mathrm{T} \mathrm{CD}^{+}$cells also come out cytokine and are important resource IFN- $\gamma$. T $\mathrm{CD}^{+}$cells in raising defense system by joining other defense system. Knowing the foreign material by immune system by itself, it does not only produce breakage material itself. Cell from immune system takes down chemistry messenger (like cytokine) which take and activate other cell like polimort, macrophage and mast cell or chemistry system (like complement, amine, kinin, and lisosomal system) to break foreign material [2].

In cupping, where local barrage happened, meridian point stimulation, hypoxia and inflamed, can repair microcirculation and cell function quickly. Fifteen days after getting cupping proved there was increasing spec trine elasticity [8], can stimulate immune of body system performance: natural killer cells [9], so immune body increased well either as prevention or rival to disease.

Beneath the skin, either muscle or fascia, there is a point, which has a special feature. Among one point to others connect horizontally and vertically form tissue. This net can be equal as meridian. With a net, there is a close relation in part of body so it forms a unity that can infect and affects other points. Medical treatment to a point can also treat the other points [10].

The research result, the mean of NK cell in pretreatment was 16.25 , standard deviation was 3.29 , the lowest value was 10 , and the highest value was 23 . While the mean of NK cell in post treatment was 35.50, standard deviation was 5.17, the lowest value was 22 , and the highest value was 45 .

The normality test used one-sample Kolmogorov-Smirnov test obtained asymp. Sig (2-tailed) NK cell value was 0.095 greater than 0.05 that meant the data is normally distributed. Homogeneity test and variance of linearity and covariance between variable were used Levene's Test of Equality of Error Variances obtained the significance of NK cell was 0.102 greater than 0.05 that meant homogeny. Because the data normality test of NK cell was normal, and in homogeneity test was fulfilled, so the test was using ANOVA obtained $p$ value was $<0.05$ that meant there was a significance difference between before and after cupping treatment.

This is similar with Ahmed that the wet cupping therapy was reported to increase the number of NK cells (Ahmed, RM, et al., 2005). NK cells are a suset of effector lymfocytes that, in contras to $\mathrm{T}$ cells, do not requieres prior sensitization with antigen for their immunologi function [7].

\section{CONCLUSION}

The conclusion of the research is cupping therapy improves the amount of T CD8+ and NK cells as form of inflammation responses. It means that the immune system rises after getting cupping therapy. Inflammation responses are forms of immune system that becomes active as self defense reaction from stressor which are considered dangerous. Based on the research result, it is suggested that cupping therapy is able to be utilized as preventive efforts of health problems.

\section{ACKNOWLEDGMENT}

The Author acknowledge to Laboratory of Medical Faculty in Brawijaya University of Malang, especially Mr. Wibi for his aid.

\section{REFERENCES}

[1] O. Barak, JR. Treat, WD James, "Antimicrobial peptides: effectors of innate immunity in the skin”, Adv Dermatol, vol. 21, pp. 357-374, 2005.

[2] SK. Schwander et al, "T Lymphocytic and Immature Macrophage Alveoltic in Active Pulmonary Tuberculosis". J of Infect Dis., vol. 173, pp. 1267-72, 1996.

[3] Baghdadi, et al., "Ameliorating Role Exerted by Al-Hijamah in Autoimmune Diseases: Effect on Serum Autoantibodies and Inflammatory Mediators". International Journal of Health Sciences, vol. 9(2), pp. 207-232, April 2015.

[4] SM. ElSayed, H.S. Mahmoud and MMH. Nabo, "Medical and Scientific Bases of Wet Cupping Therapy; in Light of Modern Medicine and Prophetic Medicine". Alternative and Integrative Medicine vol. 2, pp. 116, 2013.

[5] SH. Hong, et al, "Study on the mechanisms of cupping therapy", Zhonggou Zhen jin vol. 31 (10), pp. 932-4. 2011

[6] Ilkay Chirali, Mark Bovey, Roz Gibbs, "Cupping for Patients with inflammatory Compalints",Clinical and Biochemical Outcomes, 2005.

[7] EM. Tan, "Autoimmune antibodies, autoimmune disease, and the birth of immunologi Diagnosis”, J Clin Invest, vol. 1;122 (II), pp. 3855-6, 2012.

[8] W. Widada, "Terapi Bekam sebagai Solusi Cerdas Mengatasi Radikal Bebas Akibat Rokok", Bandung : Lubuk Agung, 2011.

[9] SM. Ahmed, NH. Madbouly, SS. Maklad, EA. Abu-Shad, "Immunomodulatory effects of blood letting cupping therapy in patients with rheumatoid arthritis", Egypt J Immunol, vol. 12, pp. 39-51, 2005.

[10] Al-Rubaye, "The clinical and histological skin changes after the cupping therapy (Al-Hijamah)", Journal of the Turkish Academy of Dermatology, vol. 6(1), pp. 1-7, 2012 